\title{
Empidoid flies from Cabo Verde (Diptera, Empidoidea, Dolichopodidae and Hybotidae) are not only composed of Old World tropical species
}

\author{
Patrick GROOTAERT ${ }^{1, *}$ \& Isabella VAN DE VELDE ${ }^{2}$ \\ ${ }^{1,2}$ Royal Belgian Institute of Natural Sciences, Vautierstraat 29, 1000 Brussels, Belgium. \\ "Corresponding author: pgrootaert@yahoo.co.uk \\ ${ }^{2}$ Email: isavelde@hotmail.com \\ ${ }^{1}$ urn:1sid:zoobank.org:author:B80BC556-9087-4D0D-9D69-7FA9BE5779C4 \\ ${ }^{2}$ urn:lsid:zoobank.org:author:CB1B2335-553C-4A40-BB10-19C62E3875C6
}

\begin{abstract}
In the present paper three empidoid fly species new to science are described from the island Sal of the Cabo Verde archipelago. Aphrosylus salensis sp. nov., a marine dolichopodid fly, is found in the splash zone of a rocky sea shore. Crossopalpus salensis sp. nov. (Hybotidae) is recorded from two different sebkhas. Crossopalpus complicatus sp. nov. is reported from an irrigated wasteland. A key to the species of these two genera occurring on Cape Verde is provided. The presence of the morphospecies Tachytrechus tessellatus (Macquart, 1842), a presumed Old World tropical species, is confirmed.
\end{abstract}

Keywords. Cape Verde, new species, Empidoidea, Aphrosylus, Crossopalpus.

Grootaert P. \& Van de Velde I. 2019. Empidoid flies from Cabo Verde (Diptera, Empidoidea, Dolichopodidae and Hybotidae) are not only composed of Old World tropical species. European Journal of Taxonomy 528: 1-17. https://doi.org/10.5852/ejt.2019.528

\section{Introduction}

Cabo Verde or Cape Verde is a volcanic archipelago some $500 \mathrm{~km}$ off the northwest coast of Africa. It consists of ten major islands, each with a typical fauna and flora. The landscapes of this archipelago are very diverse, varying from pure desserts to dense green forests due to differences in rainfall. Cabo Verde is the only Macaronesian archipelago located in the tropics.

Frey (1958) was the first to report on the Brachycera flies from the Cape Verde Islands. His study included the empidoids and he reported nine species that were collected on various islands of the archipelago. Of these nine species, Trigonocera rivosa Becker, 1902, Thinophilus indigenus Becker, 1902 and Crossopalpus aenescens Wiedemann, 1830 are so-called tramp species with an Old World tropical distribution. Five species were new to science (Frey 1958), but Hercostomus ponderosus Frey, 1958 described from the island of Sal was later considered to be a junior synonym of Tachytrechus tessellatus (Macquart, 1842), also a tramp species with an Old World tropical distribution (Grichanov 2018). 
In the present short survey of the desert-like small island of Sal, we recorded five empidoid species: one new species of Aphrosylus, two new species of Crossopalpus, a confirmation of the presence of Tachytrechus tessellatus (Macquart, 1842) and a single female specimen of Aphrosylus, diagnosed as a new species but not formally described here. Both species of Aphrosylus are different from A. lindbergi Frey, 1958, described by Frey from the Cape Verde islands of S. Vicente, S. Tiago, Rombas and Brava. The two species of Crossopalpus reported here are different from C. aenescens Wiedemann, 1830, reported by Frey (1958).

\section{Material and methods}

Specimens were both hand collected and with a sweep net on the island of Sal. The specimens are conserved in $70 \%$ ethanol in the collections of the Royal Belgian Institute of Natural Sciences in Brussels, Belgium (RBINS).

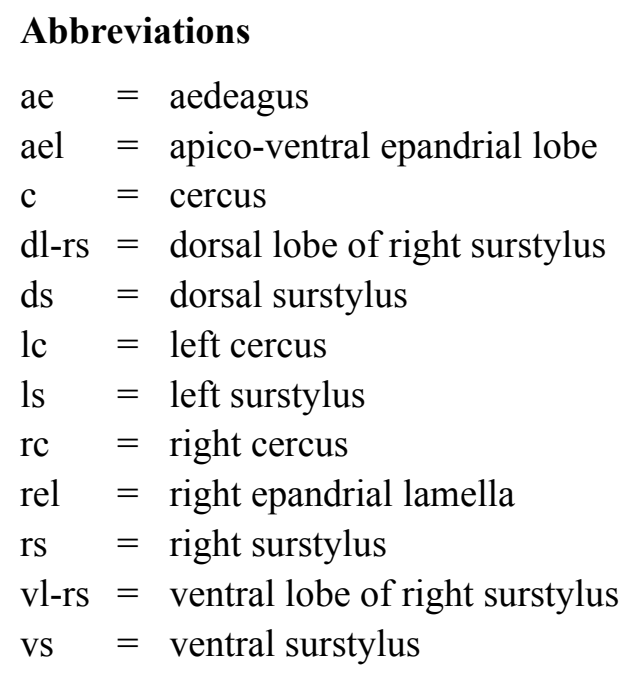

\section{Results}

Empidoidea Latreille, 1804

Dolichopodidae Latreille, 1809

Hydrophorinae Lioy, 1864

Aphrosylus Haliday, 1851

Aphrosylus salensis sp. nov. urn:1sid:zoobank.org:act:DD10D085-FFDD-4E40-B8BE-4E367DA1B063

Figs $1-2$

\section{Diagnosis}

A small species (2.1-2.3 mm) with a very long apical spur on the fore tibia. Haltere with black knob. Legs entirely black. Male with silvery shiny palpus. Male cercus pale, in lateral view with apex broadened, bearing 2-3 long black bristles with a curled tip.

\section{Etymology}

The species is named after the Island Sal where it was found; 'salensis' is Latin for 'of the island of Sal'. The name of the island Sal refers to the salt found on the island. 


\section{Type material}

\section{Holotype}

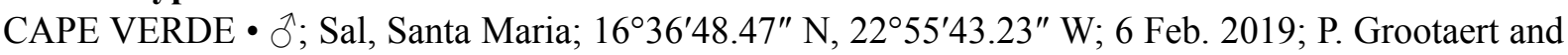
I. Van de Velde leg.; in the splash zone on rocks of a jetty; RBINS.

\section{Paratypes}

CAPE VERDE $\bullet 8$ 9 ; ; same collecting data as for holotype; P. Grootaert and I. Van de Velde leg.; in the splash zone of a rocky shore; RBINS • 2 + क ; Sal; Santa Maria; $16^{\circ} 37^{\prime} 27.26^{\prime \prime}$ N, 22 ${ }^{\circ} 55^{\prime} 51.09^{\prime \prime}$ W; 3 Feb. 2019; P. Grootaert and I. Van de Velde leg.; in the splash zone of a rocky shore; RBINS.

\section{Description}

\section{Male (Figs 1-2)}

MEASUREMENTS. Body: $2.1 \mathrm{~mm}$; wing: $1.9 \mathrm{~mm}$.

HEAD. Eyes narrowly separated on face, at the shortest distance near middle, nearly as wide as scape. Clypeus narrow, protruding, densely covered with microtrichia. Palpus white in ground colour, oval, covered with silvery hairs, inner margin with some short black hairs. A pair of strong diverging ocellars, a pair of long proclinate verticals, a pair of short postverticals. Postoculars uniseriate, black, strongest on upper part of occiput, finer below.

AnTENNA. Black. Length of scape, pedicel, postpedicel and arista in mm: 0.09:0.065:0.156:0.39. Scape longer than pedicel. Postpedicel elongate onion-shaped, twice as long as wide and arista 2.5 times as long as postpedicel.

THORAX. Black in ground colour. A large humeral, a large posthumeral, four strong dorsocentrals decreasing in length towards scutellum. The basalmost longest, twice as long as most apical dorsocentral bristle. No acrostichals present. Two short notopleurals, a long post-sutural, a long supra-alar and a pair of long crossing scutellar bristles.

WING. Greyish tinged with black veins. Posterior cross vein twice as long as apical section of the cubital vein. Haltere with a black knob.

LEGS. Black.

FORE LEG. Coxa anteriorly covered with short black spine-like bristles. Trochanter with three short spines. Femur spindle-shaped on basal half, ventrally with a double row of bristles. The posterior row is limited to the basal half of the femur. The anterior ventral row contains shorter and finer bristles. A distinct papilla is present at the ventral base of the femur, bearing a strong, blunt, curved spine; a long posterior preapical. Tibia short, somewhat spindle-shaped, with a long apical projection bearing a long curved spine. The tip of the spine reaches the trochanter. Tibia with a short posterodorsal in basal quarter and a short posterodorsal in apical quarter. Ventrally with a row of bristles increasing in length from base onwards and ending with two longer bristles on the apical projection. Tarsomere 1 with a row of interspaced fine ventral bristles, continuing on the tarsomeres 2 and 3 . Ratio of femur, tibia and tarsomeres in mm: 0.6:0.4:0.4:0:28:0.24:0.12:0.14.

MID LEG. Coxa with a short black apical spine, further covered with fine bristles, one fine exterior bristle. Mid femur thinner than fore femur. one anterior at apical fifth, one longer preapical anterior, a shorter preapical posterior. Tibia with a ventral row of very short bristles, a long anterior and long posterior near base, a long preapical posterodorsal and a long preapical ventral bristle two times as long as as width of tibia. Ratio of femur, tibia and tarsomeres in $\mathrm{mm}: 1: 0.6: 0.56: 0.3: 0.2: 0.1: 0.12$. 
HIND LEG. Coxa with a fine black exterior bristle. Trochanter with a long black dorsal bristle. Femur with four erect dorsal bristles in basal third as long as width of femur, in apical third with three long dorsal bristles longer than width of femur; one strong anterior and posterior preapical, ventral bristles lacking. Ratio of femur, tibia and tarsomeres in mm: 1:0.9:0.5:0.34:0.2:0.08:0.1.

Aвdomen. Tergites black in ground-colour, covered with short bristles. Sternites brown, covered with minute pale hairs.

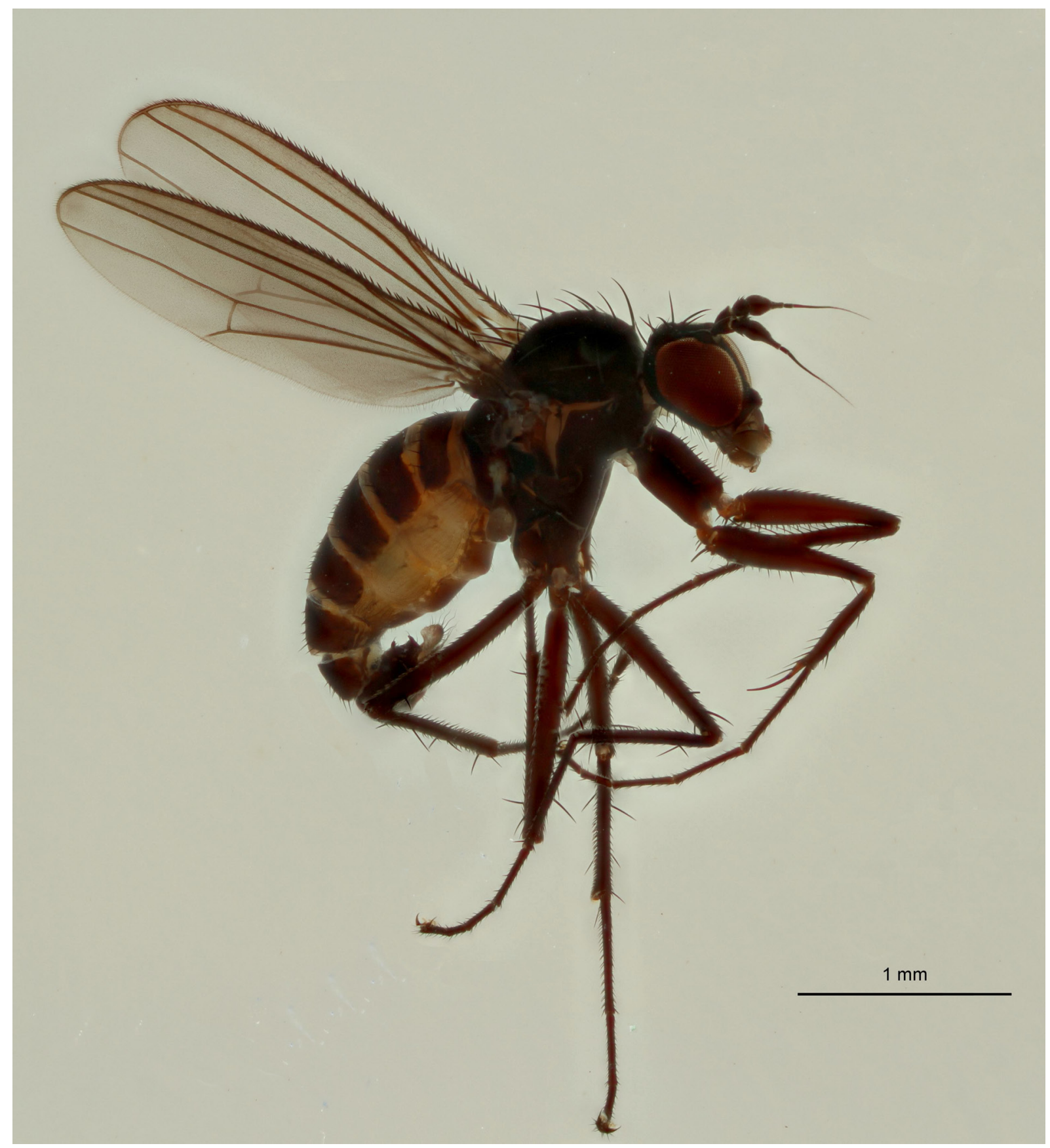

Fig. 1. Aphrosylus salensis sp. nov., male holotype, habitus (leg. P. Grootaert and I. Van de Velde, RBINS). 
Male terminalia (Fig. 2). Cerci whitish, somewhat dusky at tip. Epandrium black. Apex of cercus truncate, bordered with long black setae, some large setae with a curled tip (Fig. 2A). Base of cercus with a tubercle bearing a long seta (Fig. 2B). The tubercles of each cercus crossing. Apico-ventral epandrial lobe large, set with two setae on apex and one seta on a tubercle at the base (Fig. 2A). Ventral surstylus brown, with an enlarged apex bearing three setae (Fig. 2C). Dorsal surstylus with a large tubercle on inside bearing an apical seta directed to the base of the epandrial (Fig. 2D), with a second smaller protuberance at the base of the large tubercle, bearing a short seta pointing inward. Baso-ventral epandrial lobe small, with a single short seta.

\section{Female}

Measurments. Body: 2.1-2.3 mm; wing: 2-2.1 mm.

Similar to male in most aspects, especially the long apical projection on the fore tibia with the long spine. Scape, pedicel, postpedicel and arista in mm: 0.065:0.052:0.143:0.351.

ForE LEG. Ratio of femur, tibia and tarsomeres in mm: 1:0.6:0.66:0.28:0.2:0.12:0.22.

Tergites 3 and 4 at sides with a patch of small squamiform setae which are not present in the male.

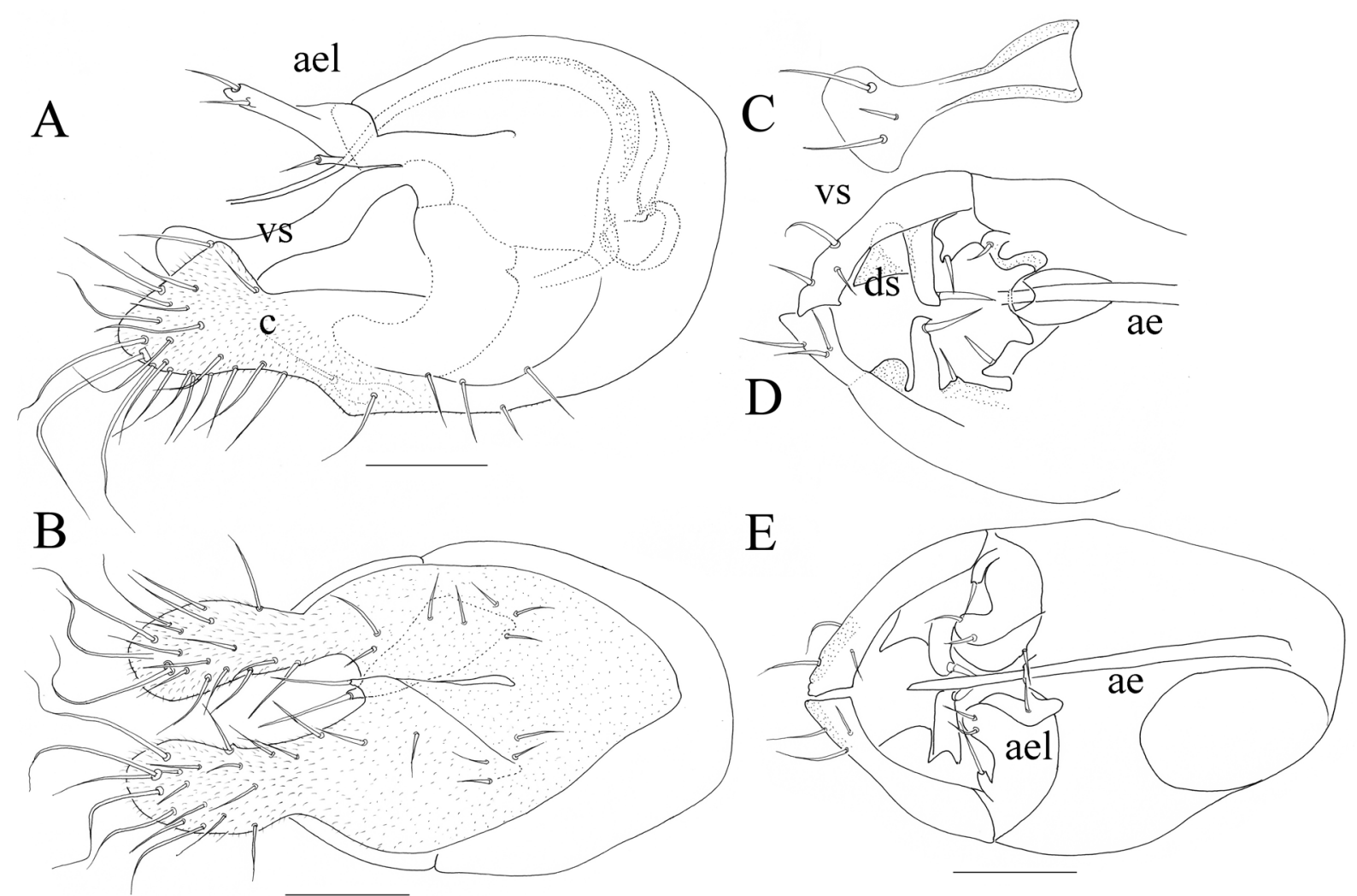

Fig. 2. Aphrosylus salensis sp. nov., male holotype, terminalia. A. Epandrium, lateral view. B. Cerci, dorsal view. C. Ventral surstylus, lateral view. D. Ventral view of epandrium, below the epandrial lobes. E. Ventral view of epandrium. Scales: $0.1 \mathrm{~mm}$. 


\section{Remarks}

The new species is closely related to Aphrosylus calcarator Frey, 1945 from the Canary Islands, especially in having a very large spur on the fore tibia. In the male $A$. calcarator, the eyes almost touch on the face ("linien formig" sensu Negrobov 1979). In the new species the eyes are distinctly separated in the male by a distance of nearly the width of the scape; in the female the distance is even wider than the scape. In A. calcarator, the postpedicel is a little longer than wide and the arista is 3.5 times as long as the postpedicel (Negrobov 1979: fig. 1573). In the new species, the postpedicel is longer, twice as long as wide, and the arista is 2.5 times as long as postpedicel. In A. calcarator, the ventral bristling of the fore femur has a different pattern, with the longest bristles in the apical $2 / 3$, while in the new species the longest bristles of the posterior ventral row are in the basal half only. In A. calcarator, the fore tibia is as long as tarsomeres 1 and 2 together. In the new species, the fore tibia is relatively shorter, as long as tarsomere 1 only. In A. calcarator, tarsomere 1 of the fore leg is narrow and elongated and as long as tarsomeres 2, 3 and 4 together. In the new species, tarsomere 1 is shorter than the following three tarsomeres together. The wing in A. calcarator is dark brown tinged, while in the new species the wing is only greyish tinged. Sternite 4 in the male of $A$. calcarator seems to bear two short exterior appendages, while there are none in the new species. The male terminalia are different in both species (A. calcarator in Negrobov 1979: fig. 1575 and Fig. 2 for the new species).

Aphrosylus salensis sp. nov. differs from A. lindbergi, the only other known species from Cape Verde, in that the postpedicel in A. lindbergi is three times as long as wide. The haltere is white and apparently there is no long spur on the fore tibia. In the new species the postpedicel is twice as long as wide. The haltere is black and there is a very long spur on the fore tibia in both sexes.

\section{Key to male Afrotropical Aphrosylus}

Modified from Rampini \& Munari (1987).

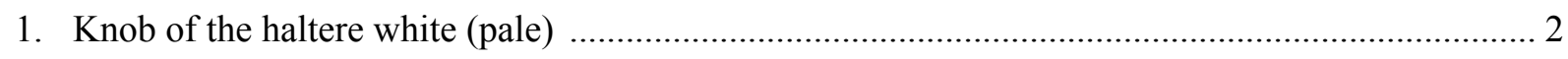

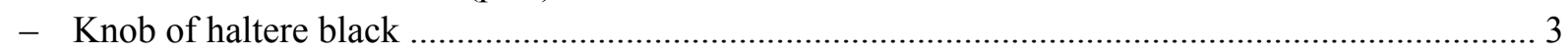

2. Postpedicel three times as long as wide, arista longer than antenna (Cape Verde)

A. lindbergi Frey, 1958

- Postpedicel at most twice as long as wide, arista as long as antenna (Sierra Leone) A. rossii Rampini, 1982

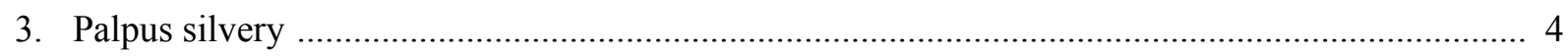

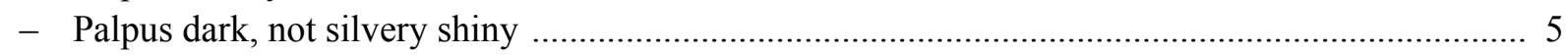

4. Postpedicel triangular, as long was wide; apical spur on fore tibia long (tibia 2.3 times length of spur); cercus in male pointed in lateral view, without long bristles (Senegal)

A. gioiellae Rampini \& Munari, 1987

- Postpedicel more bulbiform, nearly twice as long as wide; spur on fore tibia very long (tibia only 1.5 times as long as spur); cercus in lateral view with a wide apex bearing several long bristles, some with a curled tip (Cape Verde)

A. salensis sp. nov.

5. Fore and mid femora with long ventral bristles; cercus small (Sierra Leone).

A. cilifemoratus Rampini, 1982

- Fore and mid femora without long ventral bristles; cercus larger (Senegal) 
Tachytrechus tessellatus (Macquart, 1842)

Fig. 3

Dolichopus tessellatus Macquart, 1842: 185. Type locality Senegal.

Hercostomus ponderosus Frey, 1958: 15. Type locality Cape Verde, Sal, Pedra Lume.

For a complete list of synonyms we refer to Grichanov (2018).

\section{Material examined}

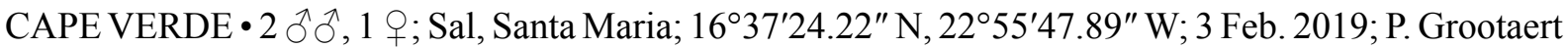
and I. Van de Velde leg.; artificial pit filled with water on the upper beach; RBINS -3 ô $\hat{\text {, }, 2} 2$ $q$, , same collecting data as for preceding; 4 Feb. 2019; P. Grootaert and I. Van de Velde leg.; RBINS.

\section{Remarks}

The present species corresponds to the morphospecies known as Tachytrechus tessellatus (Macquart, 1842) described from Senegal. It has a wide Old World tropical and subtropical distribution from

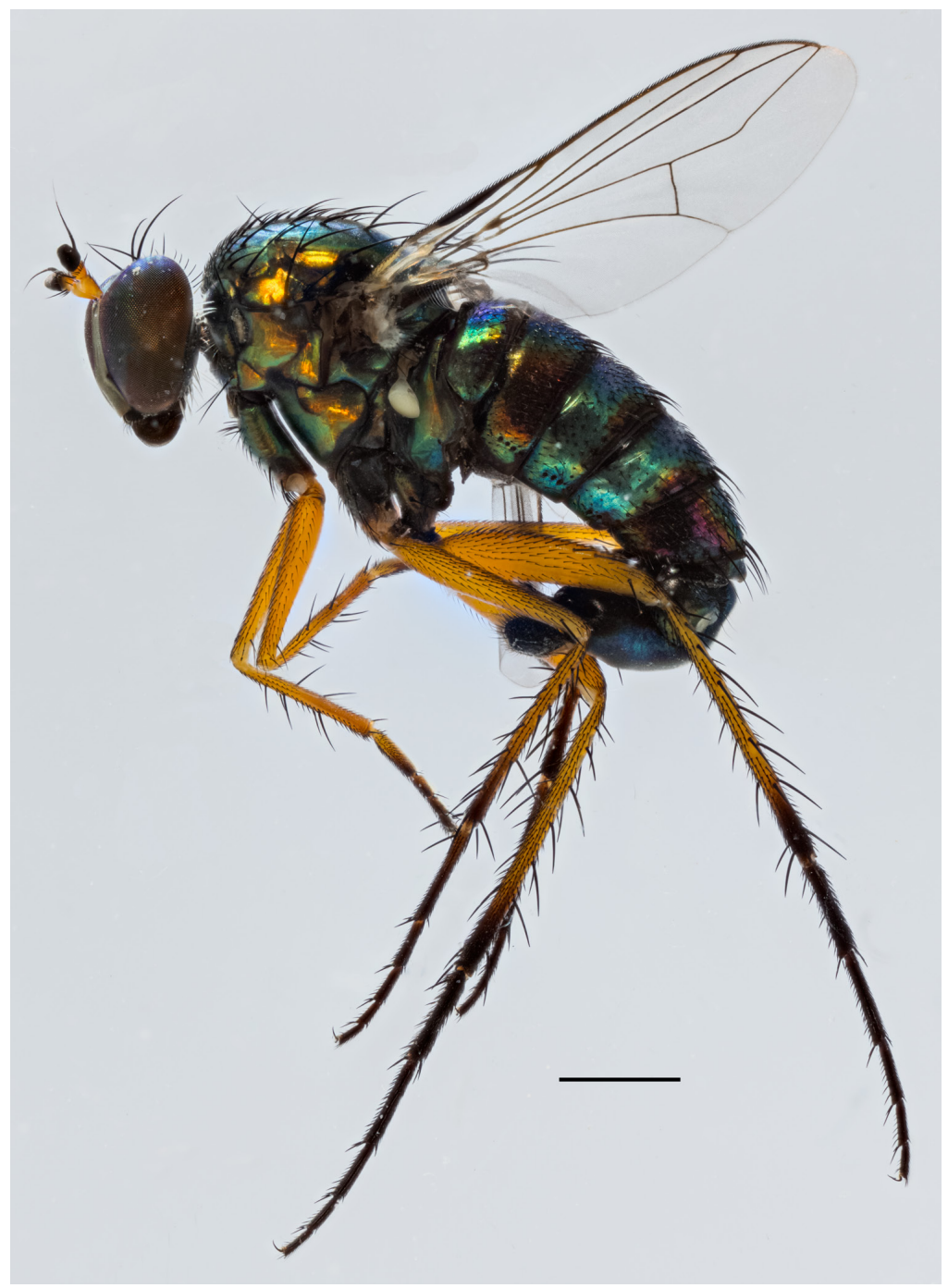

Fig. 3. Tachytrechus tessellatus (Macquart, 1842), male, habitus (leg. P. Grootaert and I. Van de Velde, RBINS; photo credit Rene Ong). Scale: $1 \mathrm{~mm}$. 
the Cape Verde archipelago in the west, all across continental Afrotropical Africa; in the Palaearctic realm it is known from Israel and Egypt, recorded throughout the Oriental Realm from the islands in the Indian Ocean, India and Sri Lanka to Indonesia and the Philippines in the east (Grichanov 2018). Recently, we also recorded it from southern Thailand and Singapore (Grootaert, Van de Velde \& Samoh, unpublished). There, it consists of two well separated populations with a barcode difference of $2.8 \%$ (Grootaert, Samoh \& Meier, unpublished).

We generally found this species along temporary bodies of water such as small lagoons on the supralittoral zone of the beach or in sun-exposed rainwater drains. On Sal, they were observed displaying on the border of an artificial water pit close to the beach.

\author{
Hybotidae Meigen, 1820 \\ Tachydromiinae Meigen, 1822 \\ Crossopalpus Bigot, 1857 \\ Crossopalpus salensis sp. nov. \\ urn:1sid:zoobank.org:act:6671B1A2-3E5D-403F-B67F-879714AB230D
}

Figs $4-6$

\title{
Diagnosis
}

Antenna entirely black. Femora and tibia black except for knees and tips. Hind tibia with long black dorsal bristles at least twice as long as width of tibia, ventrally with a row of black bristles a little longer than width of tibia.

\section{Etymology}

The species is named after the type locality, the island of Sal. The name Sal refers to the salt that was found on the island and also alludes to the saline conditions in which the species was found (Fig. 6).

\section{Type material}

\section{Holotype}

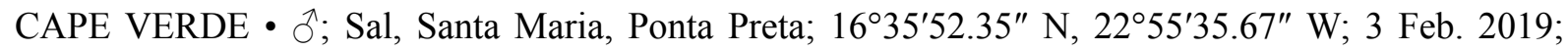

P. Grootaert and I. Van de Velde leg.; sebkha; RBINS.

\section{Paratypes}

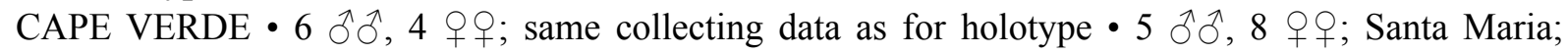
$16^{\circ} 36^{\prime} 39.30^{\prime \prime} \mathrm{N}, 22^{\circ} 55^{\prime} 0.80^{\prime \prime}$ W; 5 Feb. 2019; P. Grootaert and I. Van de Velde leg.; sebkha with open water near resorts; RBINS (Fig. 6).

\section{Description}

\section{Male (Figs 4-5)}

MeAsurements. Body: $2.24 \mathrm{~mm}$; wing: $1.6 \mathrm{~mm}$

HEAD. Black. Frons parallel-sided, as wide as scape, subshining. Eyes not touching on face, but face parallel-sided, as wide as scape, widening below. A pair of long black ocellars and a pair of long crossing black verticals. Postoculars very short, white. Antenna black, scape very short, pedicel as long as wide, with a black ventral bristle twice as long as pedicel; postpedicel a little longer than wide; stylus subapical, 2.5 times as long as all antennal segments together or 4 times as long as postpedicel. Ratio of scape, pedicel, postpedicel and stylus in mm: 0.019:0.052:0.078:0.325. 
Palpus ellipsoid, covered with pale brown hairs and one long, black apical bristle as long as palpus. Proboscis strong, shining black, nearly as long as eye.

Thorax. Shining black. Scutum seen from above triangular, narrow at the neck and there lacking the humeri (postpronotal lobe), very wide at scutellum, covered with short pale hairs and a few long bristles. The origin of the bristles is not clear due to the distortion of the triangular scutum: tentatively there are three long dorsocentrals, one long pre-sutural, one long post-sutural, one notopleural, one supra-alar and one postalar. A pair of long crossing scutellars with a minute hair at each side.

LEGS. Black except for knees of all legs yellowish brown. Tarsomere 1 of all legs yellowish-brown while following tarsomeres become gradually darker, apical most black. Apex of hind tibia with the large posteroventral spur contrastingly yellowish.

Fore LEG. Coxa covered with short pale hairs and set with a few fine black anterior bristles on apex. Femur much thickened in basal two thirds, bearing a black dorsal bristle on apical third. Ventrally with short pale hairs and a long fine black bristle as long as width of femur at base. Tibia with two strong black preapical bristles, longer than width of tibia; anteroventrally on apical half covered with short

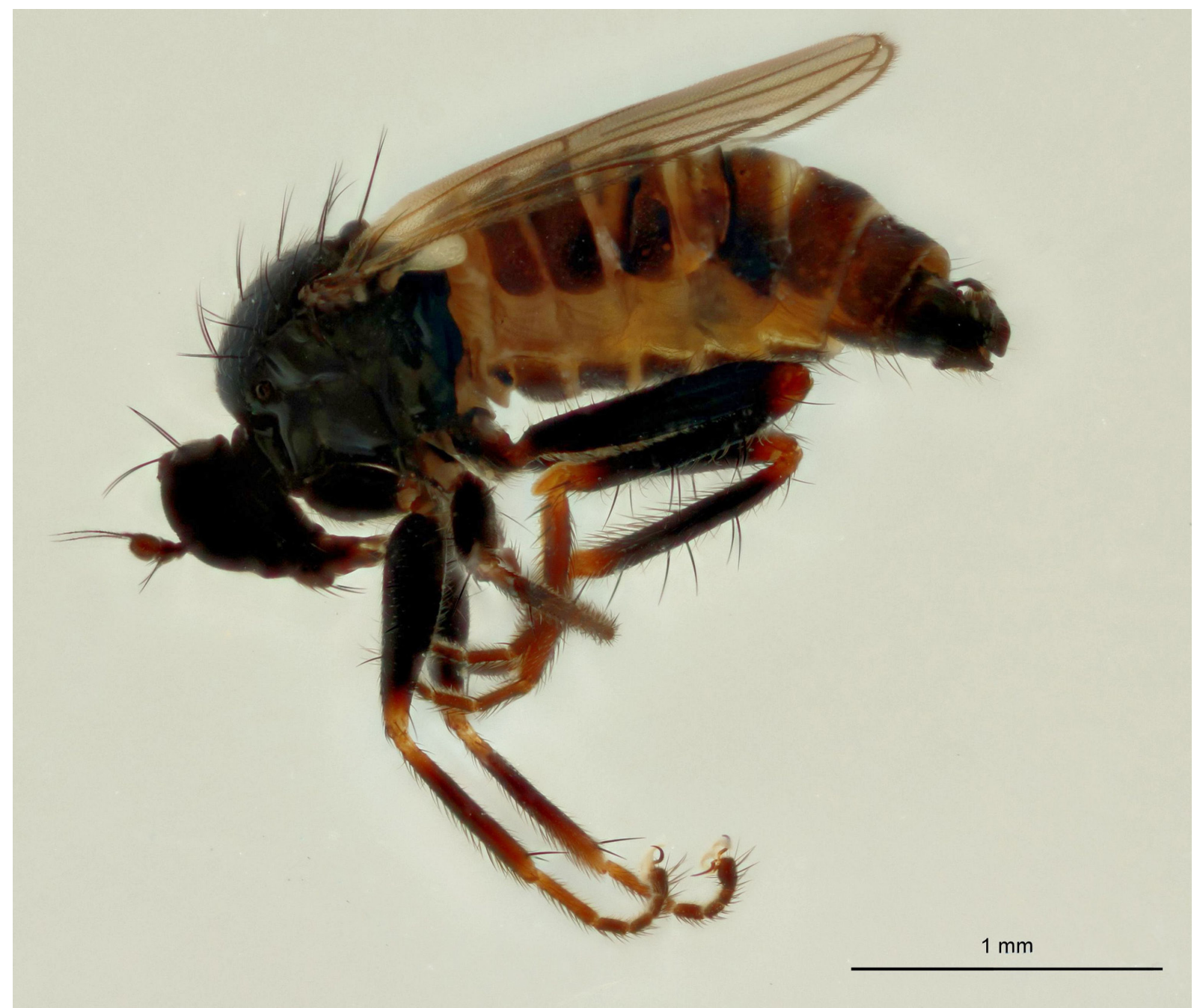

Fig. 4. Crossopalpus salensis sp. nov., male holotype, habitus (leg. P. Grootaert and I. Van de Velde, RBINS). 
pale, rather flattened hairs, anterodorsally on apical half with longer hairs. Tarsomeres 4 and 5 widened, tarsomere 5 largest.

MID LEG. Mid femur narrower than fore femur, with a long preapical anterior seta, ventrally set with white hairs; a row of dorsal setae pale on basal half, black on apical half. Tibia ventrally with short black spinules. Tarsomere 1 ventrally with pale brown spinules as long as width of tarsomere.

HIND LEG. Hind femur with an anterodorsal row of long black setae as long as width of femur. Ventrally with short pale hairs. Tibia ventrally densely set with fine brown hairs as long as width of tibia; at apex a long yellow posteroventral spur reaching over the base of tarsomere 1. Tibia with three anterodorsal setae, two posterodorsal setae twice as long as width of tibia and two short black preapical setae. Tarsomere 1 widened at base posterodorsally over the entire length, with a dense tuft of yellowish squamiform setae; four black ventral setae as long as width of tarsomere and a strong but short posterior seta near middle.

WING. Clear with yellowish brown veins. A long costal seta present. Veins R4+5 and M diverging near middle, converging before tip of wing and ending parallel in costa. Vein $\mathrm{M}$ undulating after the crossvein $\mathrm{r}-\mathrm{m}$. Cross-vein $\mathrm{r}-\mathrm{m}$ ending in cell $\mathrm{M}$ beyond middle of cell $\mathrm{M}$. Squama with numerous long white cilia. Haltere white.

AвDOMEn. Black, terminalia not wider than abdomen. Tergite 1 not sclerotized. Tergite 3 twice as wide as tergite 2 . Tergites covered with short pale hairs, some flattened setae at sides.

Terminalia (Fig. 5). Cerci not fused at apex. Right cercus narrow, left cercus very wide, with a few long bristles at right side and minute bristles at left side (Fig 5B). Apex of right epandrial lamella pointed

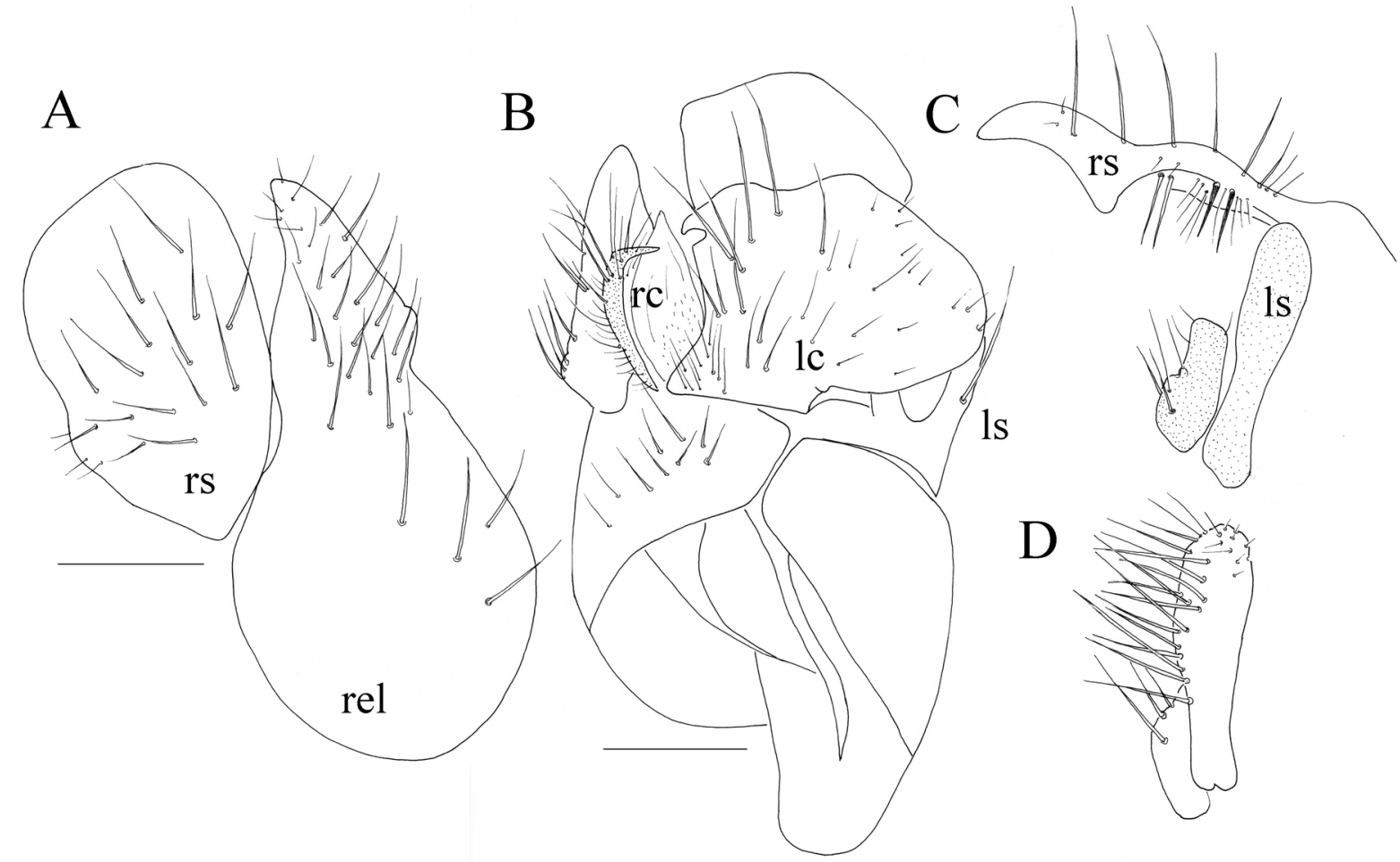

Fig. 5. Crossopalpus salensis sp. nov., male paratype, terminalia (leg. P. Grootaert and I. Van de Velde, RBINS). A. Right epandrial lamella with right surstylus. B. Dorsal view of epandrium. C. Tip of right surstylus, with left surstyli below. D. Left surstyli, lateral view. Scales: $0.1 \mathrm{~mm}$. 
(Fig. 5A), at the inside near middle with 2 short black setae. Right surstylus large, ovoid (Fig. 5A), with two small and two long brown setae at inside (Fig 5C). Left surstylus consisting of 2 lobes, left lobe longest and covered with long setae (Fig. 5D).

\section{Remarks}

The new species does not belong to the Crossopalpus aenescens group as defined by Collin (1960) and Smith (1967), since the right surstylus is a single lobe, while in the aenescens group the right surstylus is composed of at least two or three lobes (Fig. 8).

It is not clear whether the long bristles on the scutum represent the dorsocentrals and the acrostichal bristles or other bristles, since their position does not correspond exactly to the usual position.

\section{Crossopalpus complicatus sp. nov.}

urn:lsid:zoobank.org:act:F88E44C6-ED90-4A5D-A35B-D8DAB8AC5910

Figs $7-8$

\section{Diagnosis}

Antenna black but postpedicel contrastingly reddish yellow. All tibiae yellow. Hind tibiae lacking long black dorsal bristles, but long fine yellowish hairs present; ventrally with long fine black bristles twice as long as width of tibia.

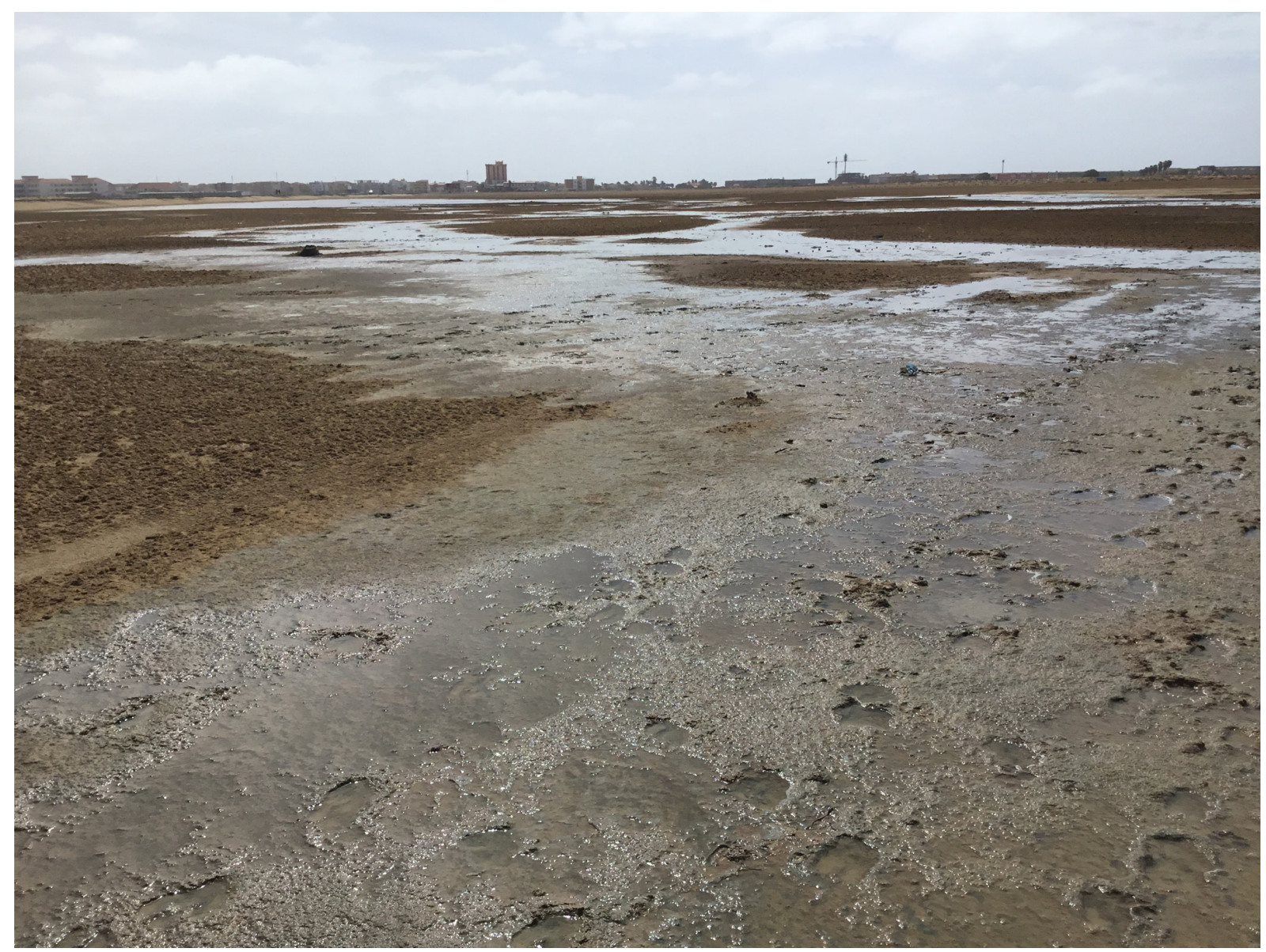

Fig. 6. View of the sebkha to the northwest of Santa Maria (Sal), where Crossopalpus salensis sp. nov. was recorded. 


\section{Etymology}

The specific epithet refers to the complicated structure of the male terminalia.

\section{Type material}

\section{Holotype}

CAPE VERDE • O’; Sal, Santa Maria; 16³6'36.50" N, 2255'27.45" W; 5 Feb. 2019; P. Grootaert and I. Van de Velde leg.; irrigated waste land; RBINS.

\section{Description}

\section{Male (Figs 7-8)}

MeAsurements. Body: $2.9 \mathrm{~mm}$; wing: $2.4 \mathrm{~mm}$

HEAD. Black. Eyes touching on face near middle, widening below toward palpi, grey dusted. Frons parallel-sided, as wide as scape, finely dusted. A pair of long proclinate black ocellars and a pair of long crossing black verticals. Postoculars short, white, uniseriate above, biseriate below. Antenna black, except for the reddish yellow pedicel. Scape very short; pedicel as long as wide, with a black ventral bristle more than twice as long as pedicel; postpedicel $1.5 \times$ as long as wide; stylus subapical three times as long as all antennal segments together or five times as long as postpedicel. Ratio of scape, pedicel, postpedicel and stylus in mm: 0.026:0.052:0.091:0.52.

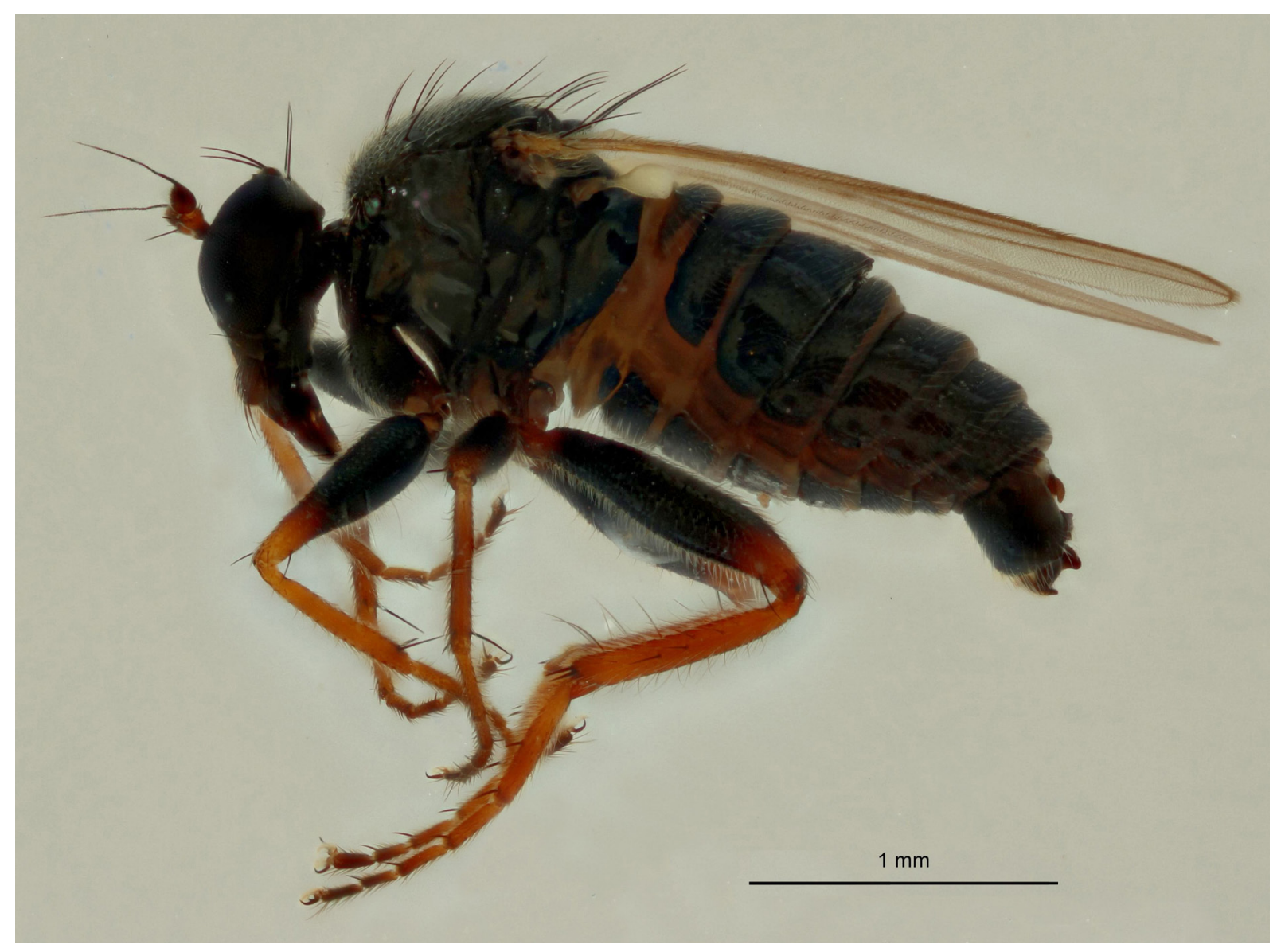

Fig. 7. Crossopalpus complicatus sp. nov., male holotype, habitus (leg. P. Grootaert and I. Van de Velde, RBINS). 
Palpus rounded, covered with white hairs and one long black apical bristle as long as palpus. Proboscis strong, shining black, half as long as eye.

THorax. Black. Pleura shiny except for a sparse dusting on mesopleura. Scutum shiny black, uniformly densely covered with short pale hairs. Five long black dorsocentrals, acrostichals lacking, two long notopleurals, one pre-sutural, one supra-alar, one postalar. A pair of long scutellars with a seta at each side, half as long as the apical scutellar setae.

LEGS. With a colour pattern. Fore coxa black, but apical margin narrowly reddish yellow. All trochanters contrastingly reddish-yellow with a ventral black spot. Fore femur shiny black, but apical quarter reddish yellow. Mid femur black, but only apical fifth reddish yellow. Hind femur shiny black, but extreme base and apical fifth reddish yellow. All tibiae and tarsomeres 1-3 reddish yellow. All tarsomeres 4 with apical half brown, all tarsomeres 5 entirely brown.

FORE LEG. Coxa protruding at base, covered with short white hairs, apical setae longer, white. Fore femur spindle-shaped enlarged in basal $2 / 3$. A long fine black anterior and a posterior preapical present. A row of white posteroventral setae in basal half nearly as long as half the width of femur, basalmost seta longer than width of femur. Tibia with a pair of long black preapicals, ventrally with inconspicuous hairs.

MID LEG. Coxa with white apical setae. Mid femur more slender than fore femur. Anterodorsally with a row of short white setae. Ventrally with short dense white hairs, basal seta longer than width of femur.

HIND LEG. Femur spindle-shaped dilated in medial two quarters, about as wide as fore femur. Dorsally with a dense white setation on basal third. Two brownish anterodorsal setae on apical quarter. About five short white anteroventral setae, less than half as long as width of femur. A white ventral seta at base twice as long as width of femur. A long preapical anterior seta, posterior preapical lacking. Tibia shorter than femur. Ventrally over entire length with white hairs at least half as long as width of tibia, the hairs are densest on apical half; two long brown ventral setae longer than width of tibia on apical half. Two stronger black anterior setae near middle. One pale and one white anteroventral setae on basal half. Apex of tibia with two short black spines and a long triangular spur, with a small subapical notch. Tarsomere 1
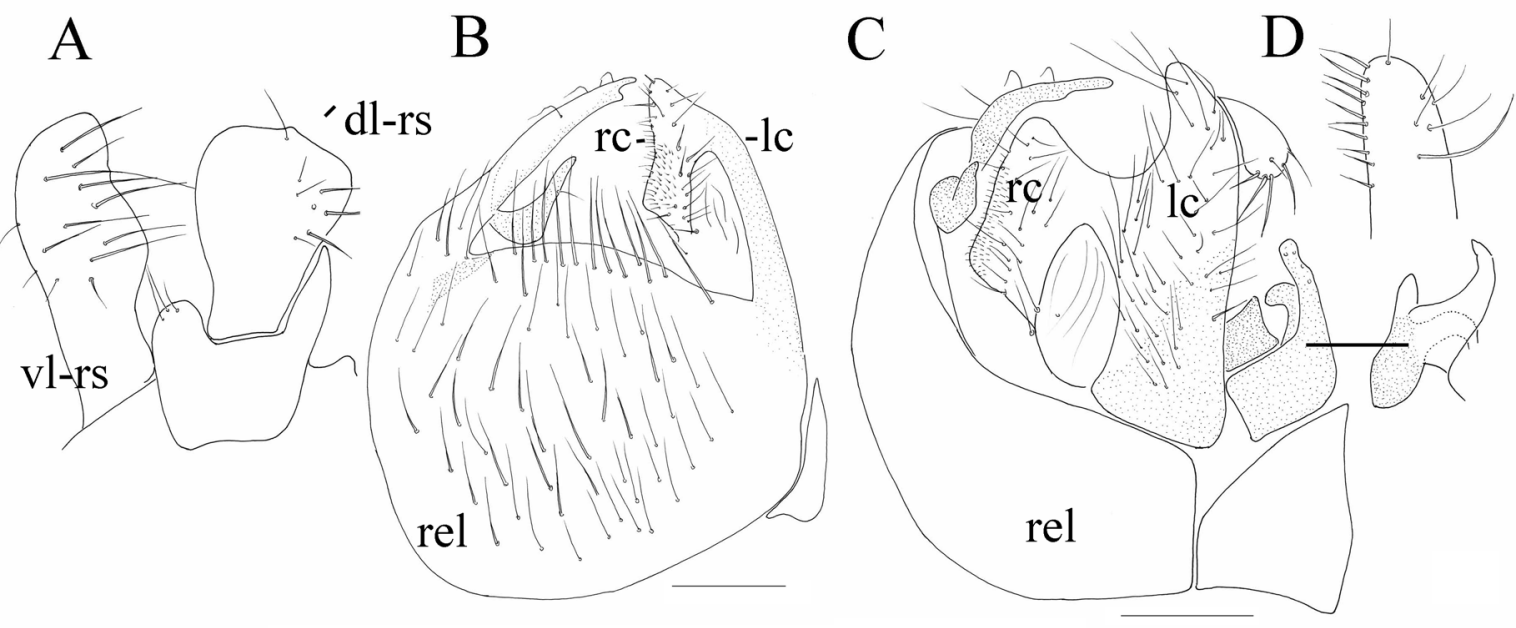

Fig. 8. Crossopalpus complicatus sp. nov., male holotype, terminalia (leg. P. Grootaert and I. Van de Velde, RBINS). A. Right surstyli. B. Lateral view of right epandrial lamella. C. Dorsal view of epandrium, with detail of left surstyli. D. Tip of right surstylus from inside. Scales: $0.1 \mathrm{~mm}$. 
long, apical $2 / 3$ posteroventrally with a dense tuft of golden, flattened hairs. Ventrally with a short black spine near middle and an apical spine.

WING. Clear with yellowish brown veins. Hairs on costa pale, basal coastal bristle long, black. Squama pale, with long white cilia. Haltere white.

AвDomen. With seven visible tergites, all shiny black and covered with fine pale hairs. Anterior half of tergite 1 not sclerotized, but posterior half strongly sclerotized. Sternites with central parts strongly sclerotized, black, covered with pale hairs, sternites 2 and 3 with a few longer marginal setae.

Terminalia. Black (Fig. 8), narrower than tip of abdomen. Cerci apically broadly fused (Fig. 8C). Right surstylus consisting of three lobes. The dorsal lobe has a wide apex with a small point on the apical border, covered with few short hairs (Fig. 8A). The ventral lobe of the right surstylus is covered with longer bristles. Left surstylus composed of two short lobes only (Fig. 8C).

\section{Female}

Unknown.

\section{Remarks}

The new species belongs to the C. aenescens-group sensu Collin 1960 as referred by Smith (1967). This group is characterized by the right surstylus, which is split up in two or more lobes. The dorsal lobe has a broad tip with a small apical point (Fig. 8A) and the ventral lobe is generally set with long bristles.

\section{Key to male Crossopalpus from Cape Verde}

1. Hind tibia with strong dorsal bristles (Fig. 4); antenna entirely black 2

- Hind tibiae with weak dorsal bristles (Fig. 7), but long ventrals; pedicel contrastingly reddish yellow, scape and postpedicel black

C. complicatus sp. nov.

2. Male terminalia large, broader than apex of abdomen (lobes of right surstylus as in figs 3-4 in Smith 1967) C. aenescens Wiedemann, 1830

- Male terminalia narrower than apex of abdomen (Fig. 4) C. salensis sp. nov.

For the identification of the Afrotropical Crossopalpus we refer to the keys of Raffone (1994) and Grootaert \& Shamshev (2012). Illustrations of the various lobes of the right surstylus of the aenescens group can be found in Smith (1967).

\section{Discussion}

The island of Sal is a small desert-like island that receives very little rain. Generally, there are hardly ten days of rain a year. Hence, it is a desert with a little vegetation, except where it is irrigated. Moreover, there are continuous strong trade winds from the east preventing insects to fly. Species of Crossopalpus are generally ground dwellers and the two species observed here mainly run around on the soil and when disturbed fly for only a short distance of half a meter each time. Crossopalpus salensis sp. nov. was found on two occasions in salt plains. They were most abundant where the soil was humid and microscopic algae formed a cover or crust with the salt on the clay. This kind of biotope is called a sebkha in North Africa. When the sebkha is continuously humid, higher plants are present and it has the aspect of a salt marsh. Figure 6 shows a situation where no higher plants are present, but in other cases where Salicornia and other higher plants are present, it looks like a salt marsh. 
A list of the species occurring in the archipelago of Cape Verde is given below.

Empidoid species occurring in Cape Verde

\section{Dolichopodidae}

Aphrosylus salensis sp. nov.

Endemic to Cape Verde

Marine, on rocky shores

Aphrosylus lindbergi Frey, 1958

Endemic to Cape Verde

Marine, on rocky shores

Chaetogonopteron nectarophagum (Curran, 1924)

syn. Chaetogonopteron gorgon (Frey, 1958)

Afrotropical, Palaearctic, Oriental

Habitat unknown

Hydrophorus praecox Lehmann, 1822

Afrotropical, Australasian, Oriental, Palaearctic, Neotropical

Halophilic

Tachytrechus tessellatus Macquart, 1842

Afrotropical, Australasian, Oriental, Palaearctic

Halophilic

Thinophilus indigenus Becker, 1902

Afrotropical, Palaearctic, Oriental

Halophilic

Trigonocera rivosa Becker, 1902

Afrotropical, Oriental, Palaearctic

Habitat unknown

\section{Hybotidae}

Crossopalpus aenescens (Wiedemann, 1830)

Afrotropical, Oriental

Halophilic

Crossopalpus complicatus sp. nov.

Endemic to Cape Verde

Non-halophilic

Crossopalpus salensis sp. nov.

Endemic to Cape Verde

Halophilic

Elaphropeza antennata nitidifrons Frey, 1958

Endemic to Cape Verde

Habitat unknown

Elaphropeza tiagoana Frey, 1958

Endemic to Cape Verde

Habitat unknown 
As can be seen from the list above, only 12 empidoid species have been recorded up to now from Cape Verde. Seven species belong to the Dolichopodidae and five to the Hybotidae. Empididae and other empidoid families are lacking. These figures are very low and not only biased by undersampling, but simply because of the arid climate on most of the islands. Five of the seven dolichopodid species have a very wide Old World distribution. The halophilic species seem to dominate and occur in extreme habitats such as sebkhas or, in the case of Tachytrechus tessellatus, in habitats with a variable salinity. Crossopalpus aenescens is the only hybotid species that has a presumed wide Old World tropical distribution. The other species seem to be endemic to Cape Verde until now.

The adaptation to extreme habitats is perhaps the reason why their distribution is so wide in the Old World. However, these morpho-species are probably species complexes and the genetic distances in relation to the geographic distances are as yet unknown.

\section{Acknowledgements}

We thank Dr Lorenzo Munari (Venice) and Dr Igor Grichanov (St Petersburg) for their help in obtaining some literature. Ms Camille Locatelli (RBINS, Brussels) and Rene Ong (Lee Kong Chian Natural History Museum, Singapore) are thanked for taking the stacked photographs. Dr Igor Shamshev (St Petersburg) gave interesting comments on the manuscript.

\section{References}

Collin J.E. 1960. Some Empididae from Palestine. Annals and Magazine of Natural History 2: 385-420. https://doi.org/10.1080/00222935908650872

Frey R. 1958. Zur Kenntnis der Diptera brachycera p.p. der Kapverdischen Inseln. Societas Scientiarum Fennica Commentationes Biologicae 18: 5-61.

Grichanov I.Ya. 2018. An Annotated Catalogue of Aftrotropical Dolichopodoidae (Diptera). Plant Protection News Supplement 25. St Petersburg. https://doi.org/10.5281/zenodo.1187006

Grootaert P. \& Shamshev I. 2012. The flies of the family Hybotidae (Diptera, Empidoidea) collected during the Boyekoli Ebale Congo 2010 Expedition in Democratic Republic of Congo. Zootaxa 3603: 1-61. https://doi.org/10.11646/zootaxa.3603.1

Macquart J. 1842. Diptères exotiques nouveaux ou peu connus. Mémoires de la Société des Sciences de l'Agriculture et des Arts de Lille 1841 (1): 65-200.

Negrobov O. 1979. 29. Dolichopodidae. In: Lindner E. (ed.) Die Fliegen der Palaearktischen Region 321: 419-474. Schweizerbart'sche Verlagsbuchhandlung, Stuttgart.

Raffone G. 1994. Terzo contributo alla conoscenza dei ditteri Hybotidi della Sierra Leone. Accademia nazionale dei Lincei 267: 219-229.

Rampini L. \& Munari L. 1987. Due nuovi Aphrosylus Walk. afrotropicali (Diptera, Dolichopodidae). Bollettino del Museo civico di Storia naturale di Venezia 37: 99-106.

Smith K.G.V. 1967. Afrikanische Empididae (Dipt.). Stuttgarter Beiträge zur Naturkunde A 179: 1-16.

Manuscript received: 9 March 2019

Manuscript accepted: 7 May 2019

Published on: 29 May 2019

Topic editor: Gavin Broad

Desk editor: Kristiaan Hoedemakers 
Printed versions of all papers are also deposited in the libraries of the institutes that are members of the EJT consortium: Muséum national d'Histoire naturelle, Paris, France; Meise Botanic Garden, Belgium; Royal Museum for Central Africa, Tervuren, Belgium; Royal Belgian Institute of Natural Sciences, Brussels, Belgium; Natural History Museum of Denmark, Copenhagen, Denmark; Naturalis Biodiversity Center, Leiden, the Netherlands; Museo Nacional de Ciencias Naturales-CSIC, Madrid, Spain; Real Jardín Botánico de Madrid CSIC, Spain; Zoological Research Museum Alexander Koenig, Bonn, Germany; National Museum, Prague, Czech Republic. 